Radoje JEVTIĆ, $\mathrm{PhD} *$

Electrotechnical school "Nikola Tesla“, Niš

doi:10.5937/bezbednost1701098J

UDK - 341.227:351.862.22::004.942

Pregledni naučni rad

Primljen: 26.11.2015.

Revizija: 26.9.2016.

Revizija: 26.6.2017.

Datum prihvatanja: 30.5.2017.

\title{
The Safety in Tunnels-An Example of Simulated Evacuation from a Railway Tunnel
}

Abstract: Railway tunnels, as special structures in terms of design and construction always present an open and current topic. A particularly important aspect related to railway tunnels is evacuation, because of their structural and physical properties and inability to predict potential catastrophes, when it is important to reach and evacuate people possibly captured inside the tunnel in as short a time as possible. The possibilities for evacuation in tunnels significantly decrease due to the narrowness of the tunnels, faster spreading of fire and smoke than in open space, tunnel length and many other reasons. It is therefore obvious that prediction of potential evacuation situations could be very difficult and complex. Beside many theoretical calculations and partial experiments, one of the safest ways for prediction and realization of evacuation is the usage of software for evacuation, such as Pathfinder, Evac Tunnel, Exodus and similar. The purpose of this paper is to show the obtained simulation results for evacuation in software Pathfinder, in the case of a 6100m-long railway tunnel with emergency exits on every $500 \mathrm{~m}$ and without emergency exits.

Keywords: Evacuation, simulation, tunnels.

"E-mail: milan.jvtc@gmail.com 


\section{Introduction}

The term 'evacuation' can be defined in different ways, but generally, it alludes to organized and planned moving of people, animals and material, cultural and other properties from an endangered object, location or area to a secure object, location or area. Evacuation can be complete or partial depending on the degree of danger and potential consequences. Evacuation can be caused by different events, including the following: thunder strikes, earthquakes, storm winds and ice, snow, flood, drought, fire, technical disturbances etc. (Jevtić, 2014).

The term 'tunnel' can also be defined in different ways, but it refers to underground facilities with two openings, with horizontal or with a slightly gradient position related to the ground that serves for different purposes: railways, roads, underground airports, water ways, storage, etc. The main role of the tunnel is to connect two or more different points separated by obstacles that could not be overcome in any other way. The highest numbers of built tunnels were definitely railway tunnels. Much lower numbers of built tunnels were for road traffic or some other purpose. There were also examples of tunnels deep in the mountains being used as protection facilities for airplanes (tunnels in Sweden, Željava near Bihać (destroyed in 1992), Slatina near Priština, Divulje near Split, Šipčanik near Podgorica and similar ones).

It is obvious that the construction of tunnels demand engaging of specialist from different scientific fields, usage of modern equipment and huge financial expenses. The factors that influence a tunnel's price are: the tunnel length, altitude, geological contents of the terrain, strength and arrangement of ground waters, terrain deformation, etc. It is obvious that tunnels present structures where the geological environment presents part of the building's construction. Although the construction of tunnels demands usage of the latest technique and equipment, the corrections during the construction are very frequent. Some examples of tunnels are shown in Figure 1. 


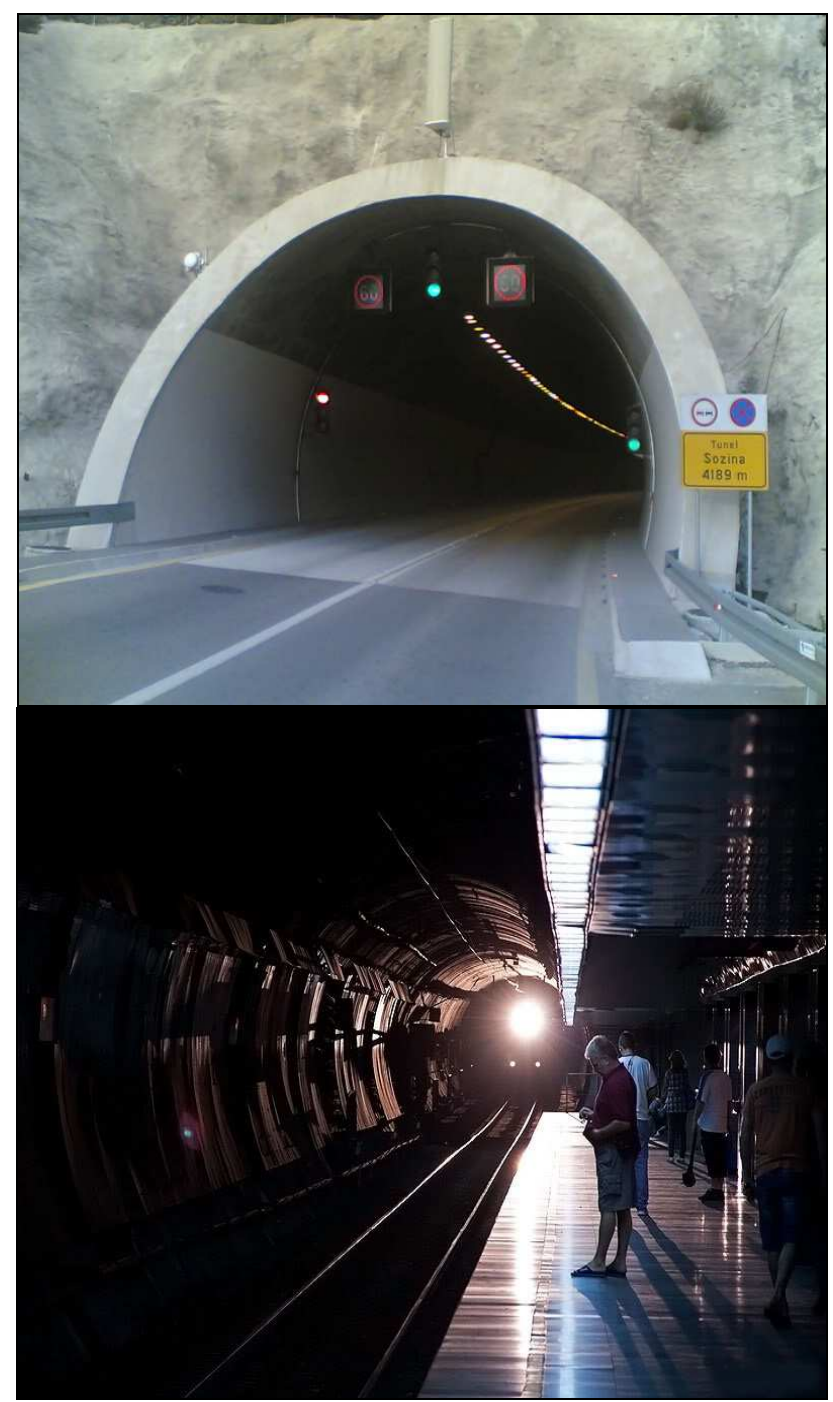

Figure 1. Tunnel Sozina in Montenegro (left) and tunnel of Belgradesubway (right) (figure

source:https://www.google.rs/search?q=zeleznicki+tuneli\&espv=2\&biw $=12$ $80 \& b i h=685 \& t b m=i s c h \&$ tbo $=u \&$ source $=u n i v \& s a=X \& v e d=0 C B o Q s A R q F Q$ oTCICZt7vFwcgCFQK8GgodGNQNiw)

The tunnels can also be divided in several ways, with reference to different factors. For example, according to the tunnel length, tunnels could be classified in small tunnels (up to $50 \mathrm{~m}$ ), short tunnels (50-500m), medium-length tunnels (500-2200 m), long tunnels (2200- 
$4000 \mathrm{~m}$ ) and very long tunnels (over $4000 \mathrm{~m}$ ). According to the number of carriageways, tunnels could be classified in tunnels with one carriageway, tunnels with two carriageways and more carriageways tunnels. According to the tunnels position related to the ground, tunnels could be classified in hill tunnels, underwater tunnels and city tunnels. According to the structure, tunnels could be classified in completely constructed tunnels, partly constructed tunnels and nonconstructed tunnels. There are also many other different divisions of tunnels (Grgić, 2008),(Jevtić, 2016).

The railway tunnels present a special type of tunnels where, beside the construction of the tunnel itself, there is a need to construct the complete infrastructure for railway needs. These structures are very complicated and demanding for evacuation in the case of some disaster, such as an explosion, earthquake, flood and similar emergencies. They could have emergency exits, but there are also lots of them without these exits because of specific features on the terrains where the tunnels were built. Some of the longest railway tunnels are presented in Table 1 (Jevtić, Blagojević, 2014), (Jevtić, 2014:19-20), (Davidović and others, 2013), (https://en.wikipedia.org).

Table 1.The longest railway tunnels in the world

\begin{tabular}{|c|c|c|c|}
\hline Name of the tunnel & Location of the tunnel & $\begin{array}{c}\text { Length of the } \\
\text { tunnel }\end{array}$ & Year \\
\hline $\begin{array}{c}\text { Gotthard Base Tunnel } \\
\text { (GBT) }\end{array}$ & Switzerland & $57 \mathrm{~km}$ & $\begin{array}{c}\text { expected to be } \\
\text { completed in 2016 } \\
\text { to be completed in } \\
2025\end{array}$ \\
\hline Brenner Base Tunnel & Austria & $55 \mathrm{~km}$ & 1988 \\
\hline Seikan Tunnel & Japan & $53.85 \mathrm{~km}$ & 1994 \\
\hline Channel Tunnel & United Kingdom & $50.5 \mathrm{~km}$ & 2007 \\
\hline $\begin{array}{c}\text { Lötschberg Base } \\
\text { Tunnel }\end{array}$ & Switzerland & $34.57 \mathrm{~km}$ & 2022 \\
\hline Koralm Tunnel & Austria & $32.9 \mathrm{~km}$ & $\begin{array}{c}\text { to be completed in } \\
\text { New Gunjiao Tunnel }\end{array}$ \\
\hline Guadarrama Tunnel & Tibet & $32.64 \mathrm{~km}$ & 2014 \\
\hline West Qinling Tunnel & $\begin{array}{c}\text { Gansu Province, north- } \\
\text { west China }\end{array}$ & $28.236 \mathrm{~km}$ & 2014 \\
\hline Taihang Tunnel & China & $27.848 \mathrm{~km}$ & 2007 \\
\hline
\end{tabular}


Disasters that could happen in railway tunnels could have unforeseen consequences on human lives and could cause material damage. In the past, there were lots of accidents in railway tunnels (train wrecks, brake malfunction, explosion and similar). One of the worst was on 03/01/1944 in the tunnel near Tore del Bierzo, in the Leon mountains in Spain, where, according to the estimated figures, over 500 people lost their lives in the train wreck. These and similar facts show the importance of analysing potential accident scenarios in order to prevent damage and protect human lives and material property.

Similar research of possible fire and evacuation scenarios in road and railway tunnels was carried out in many countries, although for different purposes, focusing on the time necessary for a tunnel evacuation, safety criteria for tunnel occupants, heat transfer for different fire scenarios in tunnels, fire and smoke propagation in road and railway tunnels, smoke visibility in tunnels during fire, modelling crowd evacuation from road and railway tunnels, occupant movement and behaviour under panic and stress and many other issues. There were a lot of important results noted as the result of research (the usage of evacuation routes, evacuation under the influence of toxic and other dangerous materials, movement models of occupants under evacuation in tunnels and a lot of others), but of course one of the most important facts is that a great number of those researches were realized by simulations and with the usage of simulation software, which was absolutely safe-on the other hand, it would be necessary to test evacuation simulations with humans in real conditions which could be very dangerous and could have unforeseen consequences. Similar results for evacuation times from tunnels were obtained for the road tunnel Straževica in Serbia. The methodology of evacuation from fire endangered areas in Serbia was regulated by Technical reference TP 21 from 2002. This regulation still does not apply to all types of objects (Persson, 2002), (Norén and others, 2003), (Directive 2004/54/EC, 2004), (Yang and others, 2006), (Yang and others, 2006), (Nilsson and others, 2009), (Ronchi and others, 2012), (Caliendo and others, 2012), (Mu and others, 2014), (Jevtić,2016).

According to the aforementioned, the benefits of the simulation software usage for evacuation are obvious. One of the safest, as well as the most successful, most economic, most correct and most frequently 
used ways for potential occupant evacuation in different accident scenarios is the usage of the simulation software designed for these purposes. The research and results in this paper were obtained using Pathfinder 2012 software. This software presents an agent based on egress and human movement simulator and it provides a graphical user interface for simulation design and execution as well as 2D and 3D visualization tools for result analysis. Pathfinder can provide two different simulation models: one, where occupants are moving to their goals with avoiding other occupants and obstacles (Steering model) and other, where the occupants speed and the doors flow rates are included (SFPE model). An example of evacuation situation in a particular object at a particular time moment, in Pathfinder, is presented on Figure 2 (Thunderhead, 2012), (Jevtić, 2016).

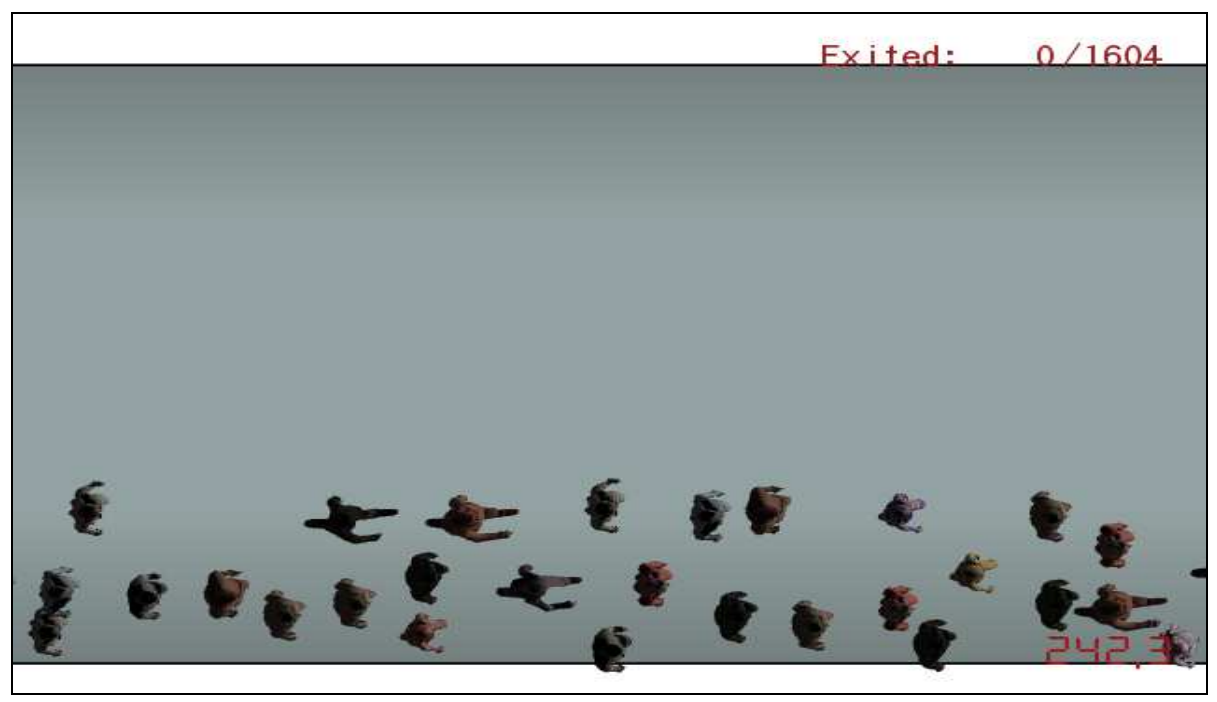

Figure 2.The example of evacuation situation in the tunnel simulation model after 242.3 seconds from the start of the simulation

\section{Simulation model}

The first task in the simulation realization is to create the simulation model of the desired object- in this case, the tunnel and train with the specific dimensions. Beside Pathfinder software, it is possible to create a simulation model in some other program, such as Auto Cad or PyroSim and insert it into Pathfinder program, which could significantly decrease complete design time. Pathfinder 
simulation software used methodology that was developed by NFPANational Fire Protection Association.

The simulation model of the railway tunnel was designed with the following dimensions: $6100 \mathrm{~m}$ length, $12 \mathrm{~m}$ width and $5 \mathrm{~m}$ height. The simulation model was designed without emergency exits, for the first scenario, and with emergency exits on every $500 \mathrm{~m}$, for the second scenario. The main reason for that was to compare evacuation times in both cases and conclude the potential advantages or disadvantages. Also, it could be possible to analyse some other parameter on evacuation in some other program, such as air flow or heat transfer, in PyroSim. In that case, the simulation model in Pathfinder must be changed into the adequate form and extension appropriate for PyroSim. For both scenarios, there were four different cases, for the occupant's speeds of $1.25 \mathrm{~m} / \mathrm{s}, 2 \mathrm{~m} / \mathrm{s}, 2.5 \mathrm{~m} / \mathrm{s}$ and $3 \mathrm{~m} / \mathrm{s}$. The whole train composition was located in the middle of the tunnel. The train had maximum passengers load, which meant that the passengers number was 1604 (20 carriages with 80 passengers per carriage and four personal members in the locomotive) (Galea, 2013), (Valasek, Glas, 2013).

It is very important to note the main limitations of this kind of simulation experiment. It was implied that the train was used for passengers transport; it was not cargo train, which would make the simulation much more complicated. Different cargo types, with their own fire, explosion, toxic, smoke or other properties could have significant influence on evacuation times and evacuation routes. For example, an explosion of a tanker with oil, gas or similar could cause the blocking in tunnels and a completely different epilogue. Passengers were designed according to the Pathfinder form and all of them were the same size while in reality, the passengers are completely different in the sense of dimensions. Noted fact also implies that the speeds of passengers must be different while in the simulation every passenger has the same speed like any other passenger.

The train was simulated according to its real dimensions, with 20 passengers' carriages and a locomotive. The carriage itself is presented on Figure 3 while the dimensions of the passenger carriage are presented in Table 2 (http://www.zeljeznice.net/ forum/index.php?/topic/12787-beemt-vagoni/). 


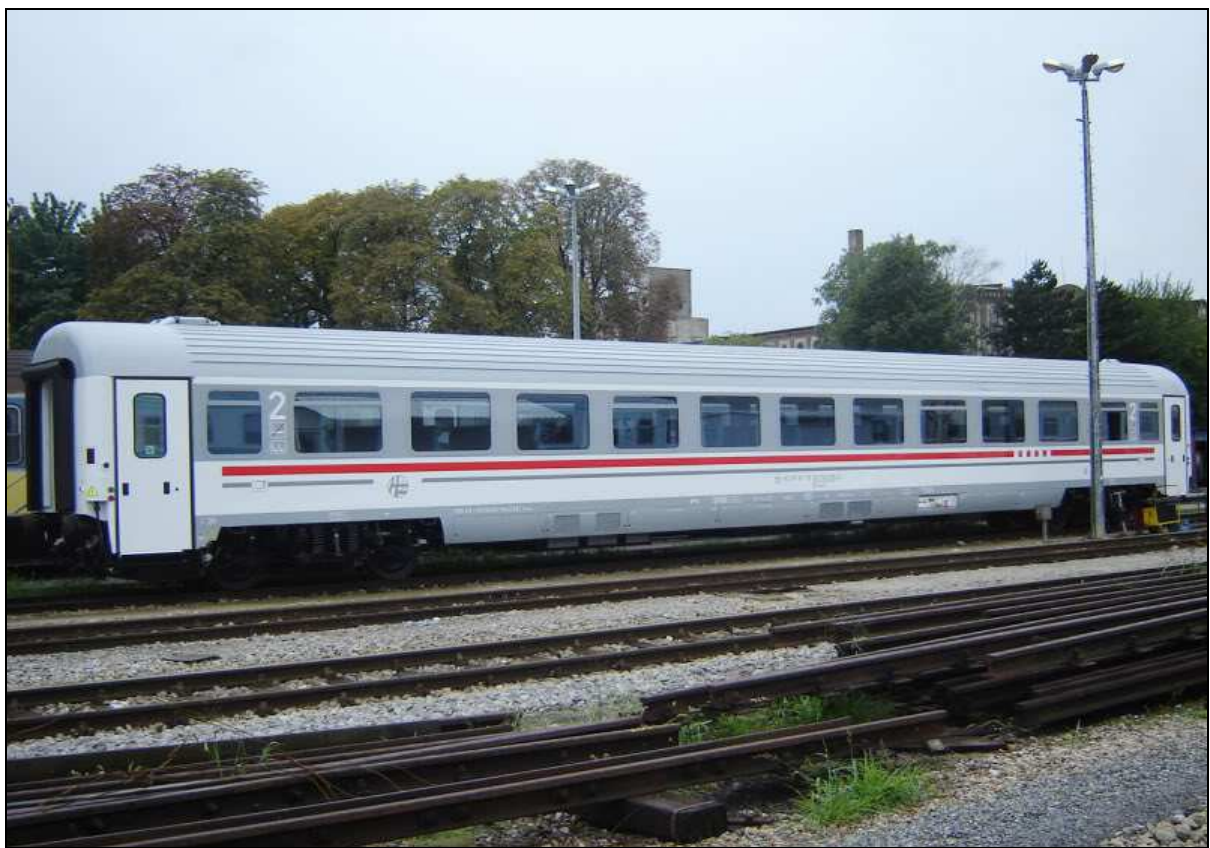

Figure 3. The Beemtcarriage (figure source:

http://www.zeljeznice.net/forum/index.php?/topic/12787-beemt-vagoni/)

Table 2. The specification of the passenger carriage(data source:

\begin{tabular}{|l|l|}
\hline Letter sign of carriage & Beemt \\
\hline Number sign of carriage & $617820-70$ \\
\hline Carriage type & UIC-Z1 \\
\hline $\begin{array}{l}\text { The place and the year of } \\
\text { production }\end{array}$ & $\begin{array}{l}\text { GOŠA, SmederevskaPalanka, Serbia, } \\
1991 .\end{array}$ \\
\hline Mass of the carriage & $50-51000 \mathrm{~kg}$ \\
\hline Drive speed & $160 \mathrm{~km} / \mathrm{h}$ \\
\hline Carriage class & 2 \\
\hline Number of compartment & No compartment \\
\hline Number of seats & 80 \\
\hline Maximal length & $26400 \mathrm{~mm}$ \\
\hline Box width & $2825 \mathrm{~mm}$ \\
\hline Maximal height & $4050 \mathrm{~mm}$ \\
\hline
\end{tabular}




\begin{tabular}{|l|l|}
\hline Floor height & 1255 \\
\hline The wheelbase & $2500 \mathrm{~mm}$ \\
\hline The width of railway track & $1435 \mathrm{~mm}$ \\
\hline Number of axis & 4 \\
\hline Rotation base type & GOŠA 101-1 (Minden-Deutz 522) \\
\hline Brake type & $\begin{array}{l}\text { Knorr KE-PR-Mg-D-Ep (Electro air + } \\
\text { Mg) }\end{array}$ \\
\hline Carriage heating & Electro heat air \\
\hline Carriage cooling & Electro air \\
\hline Carriage illumination & Electro fluorescent \\
\hline Toilet & Closed vacuum system \\
\hline
\end{tabular}

\section{Simulation and simulation results}

Every simulation software with visualization possibilities demands strong computer machine, with strong processor and a lot of RAM memory. Limited size of paper makes it impossible that every simulation result should be presented and for that technical reason, only some evacuation situations that presented a small part of the obtained simulation results from the first scenario are presented on figures from 4 to 10 as examples.

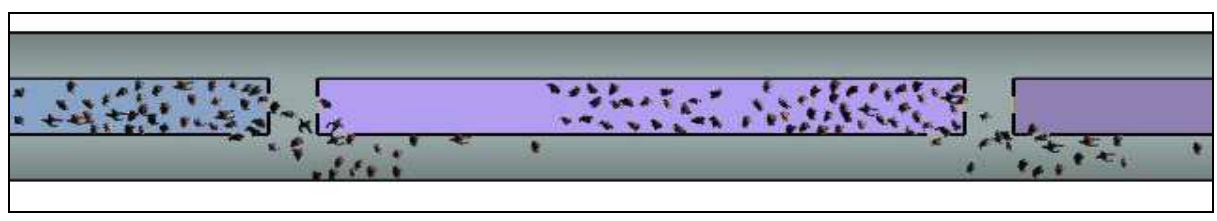

Figure 4.Evacuation situation for the first scenario after 3.7 seconds from the start of the simulation

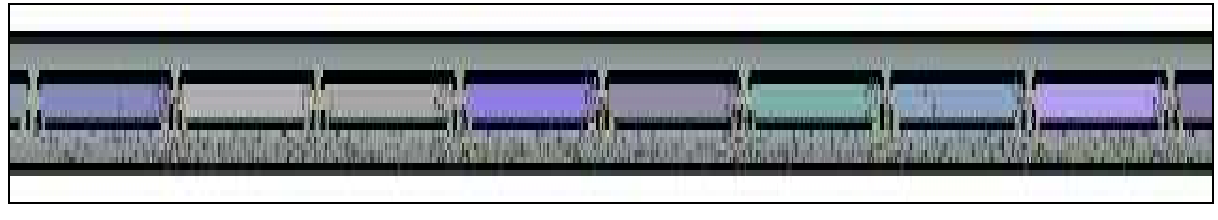

Figure 5. Evacuation situation for the first scenario after 14.8 seconds from the start of the simulation 


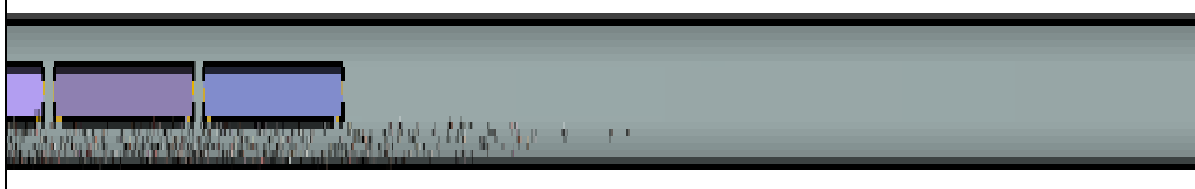

Figure 6. Evacuation situation for the first scenario after 26.8 seconds from the start of the simulation

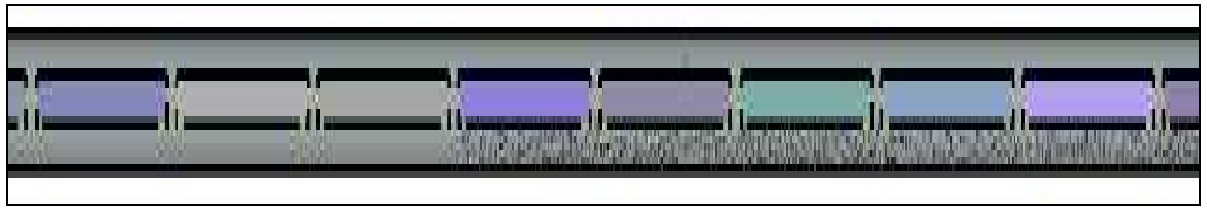

Figure 7. Evacuation situation for the first scenario after 59.2 seconds from the start of the simulation

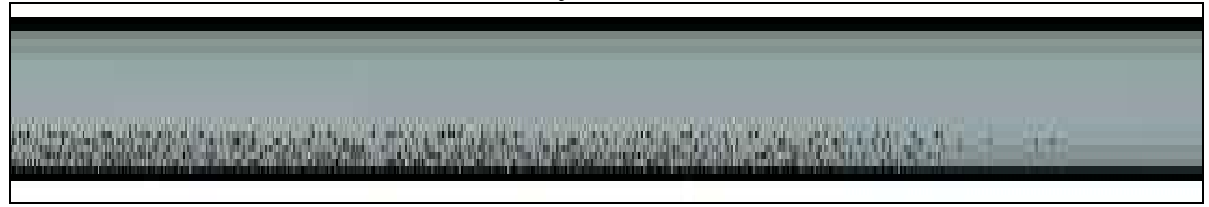

Figure 8. Evacuation situation for the first scenario after 99.9 seconds from the start of the simulation

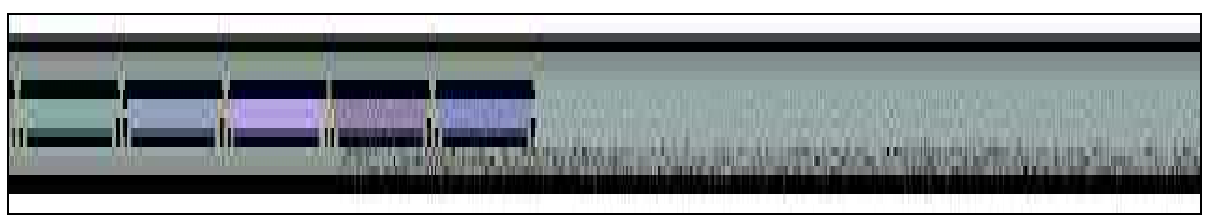

Figure 9. Evacuation situation for the first scenario after 123.1 seconds from the start of the simulation

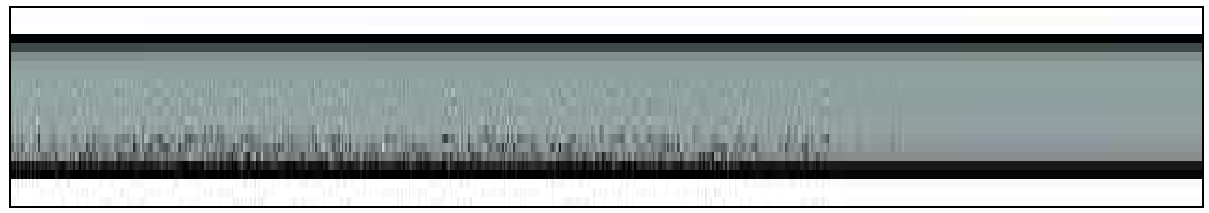

Figure 10. Evacuation situation for the first scenario after 246.2 seconds from the start of the simulation

The presented figures showed the train passenger movement and direction of their movement in different time intervals from the simulation start for the first simulation scenario which implied a tunnel without emergency exits. The fact that the tunnel length was $6100 \mathrm{~m}$ 
was the reason for figures presentation. The figures actually present screenshots in the determined time moment from simulation. During the simulation, it was possible to see, in every moment of simulation, the number of passengers that left the tunnel and the number of the remaining passengers.

\section{Discussion}

The complete simulation results, which included total time needed for evacuation of all passengers, for both scenarios, are presented in Figures 11 and 12, although every simulation was performed separately.

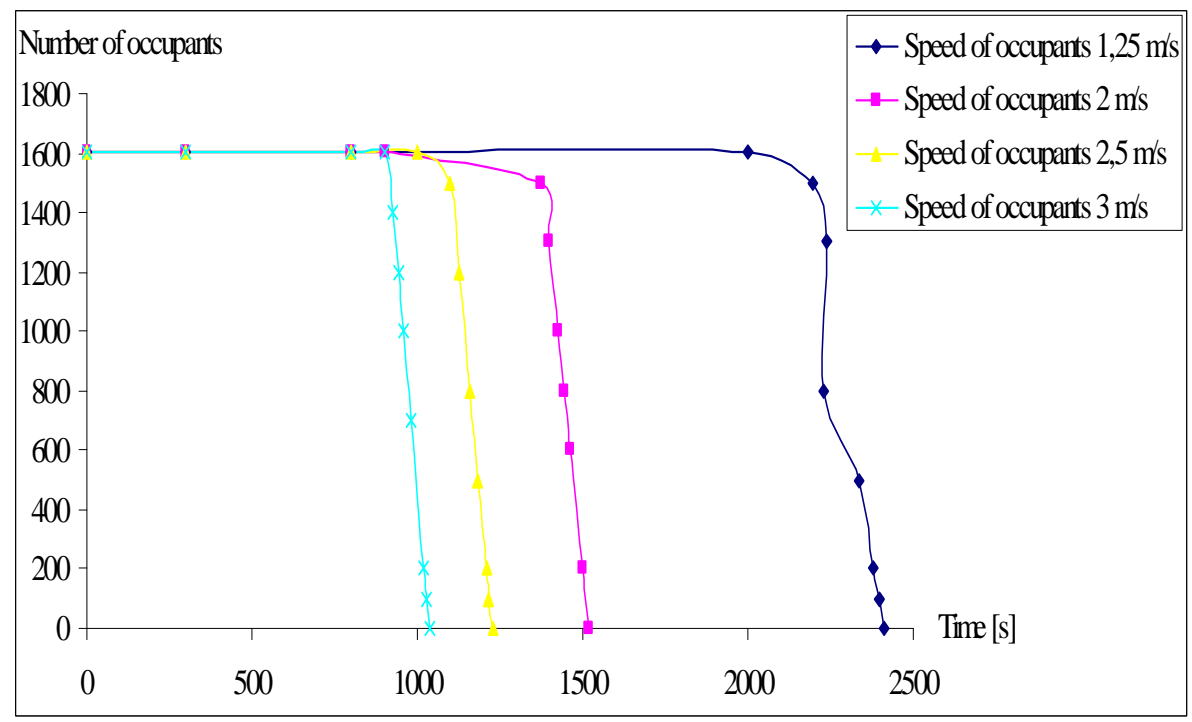

Figure 11. Simulation results for the first scenario without emergency exits 


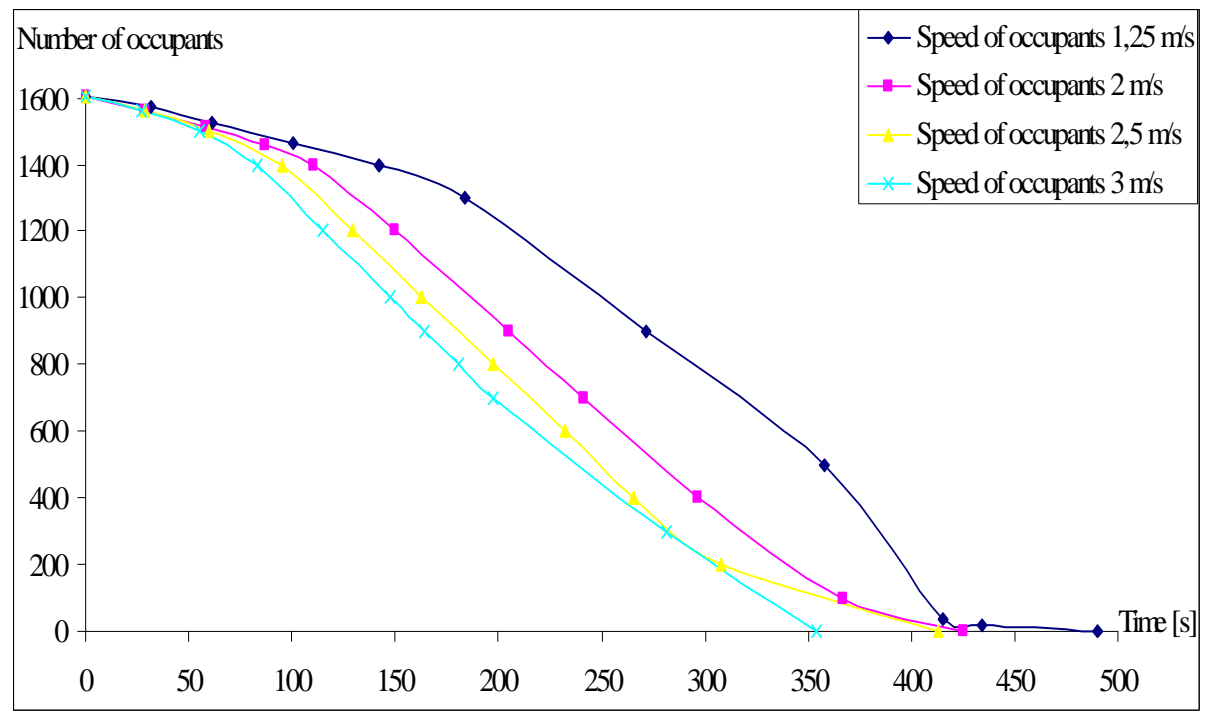

Figure 12. Simulation results for the second scenario with emergency exits

The simulation results mostly showed the expected directions, ways and times for complete tunnel evacuation for both scenarios, with and without emergency exits. But, it is a known fact that every tunnel could not have emergency exits for many reasons, for example, because of its geographic position and location, because of its purpose, because of ground contents, ground waters presence, etc. It is obvious, according to the simulation results that the higher speed of occupants could lead to congestions, because, in that case, occupants cannot get out from the carriage quickly. Even in the case where there were fewer emergency exits, the complete evacuation times had been shorter than in the case without any emergency exits. This simulation of the evacuation example implied only a simple leaving of the train that was stopped in the middle of the railway tunnel, but, it is very important to note, that this and similar software could analyse much more complicated situations, such as fire influence on occupants evacuation, air flow influence on smoke in the tunnel or some other closed space and many other potential situations that could happen and on which all information is needed for saving human lives (Netcu and others, 2011), (Jevtić, Blagojević, 2013), (Jevtić, 2015), (Jevtić, 2016).

It is a well-known fact that in tunnels there are, more or less, air flows that could have significant effects on the fire development in a tunnel or on smoke and toxic material distribution in a tunnel. There 
are different factors that could have influence on air flow movement in railway tunnel: train movements, natural or mechanical ventilation, piston effect, different gases emissions, buoyancy and similar ones. Fire, explosion, smoke and toxic material could be made by different train accidents in the tunnel, for example. According to the obtained simulation results, it is important to know many different parameters to know potential effects on passenger evacuation from tunnel. For example, a tunnel of $6656 \mathrm{~m}$ in length, with natural ventilation velocity of $1 \mathrm{~m} / \mathrm{s}$ and density of $1.30 \mathrm{~kg} / \mathrm{m}^{3}$ contains 400 tons of air. In that kind of tunnel, for example, when the fire source is about at the middle of the tunnel (the firepower of fire source being $20 \mathrm{MW}$ ), heat transfer does not bear effect on the flow rate and the maximum temperature is about $60^{\circ} \mathrm{C}-$ it is the temperature that people can stand without protection (Daeron, Ruffin, 2000). The development of smoke and toxic material can be different according to their type - for example, chlorine and ammonia could be transported in truck tankers as liquefied gases under pressure and it is assumed that $30 \mathrm{~m}^{3}$ of product are transported in a container $2.5 \mathrm{~m}$ in diameter and $7 \mathrm{~m}$ in length. According to some results obtained in road tunnel, chlorine, which is heavier than air, progressively accumulated towards the floor while the dispersion of ammonia, which is lighter than air, appeared to be more influenced by diffusivity than by gravity, which could be particularly important for the first scenario of this paper where emergency exits did not exist (Bubico and others, 2014). The noted facts also showed the great significance of evacuation scenario simulations aimed at solving a very complicated problem of evacuation dependent on many different parameters.

The simulation results obtained in this paper were mostly in accordance with similar domestic or foreign researches. Of course, there are lots of different parameters and conditions that should be taken into account. The main task where the results were in accordance with similar earlier results is that the time needed for total evacuation from a railway tunnel with emergency exits is less than the time needed for total evacuation from a railway tunnel without emergency exits. Also, the speed of passengers is very important because jams could occur at higher speeds. Simulation results for the passenger speed of $1.25 \mathrm{~m} / \mathrm{s}$ is particularly similar with earlier simulation results, while for simulation results for passenger speed of $3 \mathrm{~m} / \mathrm{s}$ there were 
some differences. This was expected because the conditions and parameters applied in this paper were original. It is also obvious that for different types of passenger carriage (different carriage dimensions, different arrangement of seats, different width of exit/enter doors and similar) simulation results would be different, as well as for different tunnel infrastructure(Howarth, Griffin, 2011), (Wang, Jacqueline, 2014), (Jevtić, 2016).

Some references related to future researches would concern different train position in the tunnel (close or far from exit/entrance, normally positioned or turned over and similar), different arrangement of passengers at the moment of evacuation start, evacuation scenarios under different fire load and different position of fire load and similar.

\section{Conclusion}

Real evacuation of some particular building and/or event can be very complex, hard to perform and, which is always the biggest problem, very unpredictable, although all the rules, plans and law regulations were taken into consideration. In order to provide maximum success for evacuation with minimal risk for humans, it is necessary to predict, as much as possible, all factors that can have influence on evacuation and their consequences. Usage of the simulation software allows for some evacuation situations and scenarios to be predicted and analysed. For example, one of above noted factors is an occupant's speed. For different speeds, the evacuation time will be different and that can be calculated. Also, many occupants with higher moving speed (caused by panic, for example) can cause jams that can be crucial for evacuation time. By using the simulation software and their visual potentials, it is possible to note potential points where occupants can be jammed and eliminate them. It is possible to do all of the aforementioned without endangering the safety of occupants. The simulation results presented in this paper for a railway tunnel prove this fact.

Simulation software usage has many benefits for evacuation, especially for its safety aspect, and definitely presents the important, powerful and inevitable engineer's tool for the successful analysis of the evacuation. Even in the situations when it is almost impossible to create an adequate evacuation scenario (for example, fan fight at a 
football stadium or help to victims in an earthquake) usage of simulation software can give directions as to where the solution can be found.

\section{References}

1. Bubico, R., Mazzarrota, B. and Verdone, N., (2014). CFD analysis of the dispersion of toxic materials in road tunnels, Journals of loss prevention in the process industries, pp. 47-59.

2. Caliendo, C., Ciambelli, P., De Guglielmo, M. L. and Russo, P., (2012). Simulation of people evacuation in the event of a road tunnel fire, SIIV-5th International Congress-Sustainability of road infrastructures 2012, Rome.

3. Daamen, W., Hoogendoorn, S. and Lundgren, N., (2007).Passengers evacuating in rail tunnels, https://trid.trb.org/view.aspx?id $=801666$.

4. Daeron. S, Ruffin. E., (2000). Calculations for fire smoke behaviour in long rail tunnels, IInternational Conference "Tunnels and Underground Station Fires", Hong Kong.

5. Davidović, M., Hadžiefendić, N. and Trifunović, J., (2013). Opasnostodpožarausledkorišćenjaelektroinstalacionihkompone ntilošegkvaliteta-produžnikablovi, Bezbednost, 55(1): 140-160.

6. Directive 2004/54/EC (2004). Directive 2004/54/EC on minimum safety requirements for tunnels in the Trans-European Road Network, Official Journal of the European Union. L.167, Bruxelles.

7. Galea, R.E., (2013). The Development and Validation of a Rail Car Evacuation Model, Proceedings of the 13th International Fire Science \& Engineering Conference INTERFLAM 2013, Interscience, pp.1013-1034.

8. Grgić, I., (2008). Specifičnostigeodetskeosnove, Magistarskateza, Geodetskifakultetsveučilišta u Zagrebu, Zagreb.

9. Howarth, H and Griffin, M. J. (2011). COMFORTABLE SARDINES: THE BALANCE BETWEEN COMFORT AND CAPACITY, University of Southampton, Institute for sound and vibration research.

10. http://www.zeljeznice.net/forum/index.php?/topic/12787-beemtvagoni/, dostupan 10.01.2015.

11. https://en.wikipedia.org/wiki/List_of_longest_tunnels_in_the_world, доступан 10.01.2015. 
12. Jevtić, B. R, Blagojević, Đ. M., (2013). Simulation of the school object evacuation, Tehnika elektrotehnika ,2: 365-370.

13. Jevtić, B. R, Blagojević, Đ. M., (2014). On a linear fire detection using coaxial cables, Thermal Science, 18(2): 603614.

14. Jevtić, B. R., (2014). Simulation of the shopping center Zona I evacuation, Tehnika Elektrotehnika, 3: 537-541.

15. Jevtić, B. R., (2014). The fire and burglary protection using by no typical electrical lines, $\mathrm{PhD}$ thesis, University of Niš, Niš.

16. Jevtić, B. R., (2015). The influence of Air Flow Speed on Fire Propagation in Object, Arhitektura i urbanizam, 40: 59-65.

17. Jevtić, B. R., (2016). Evacuation from tunnels-an example of Straževica tunnel, VojnotehničkiGlasnik, 64(3): 754-768.

18. Jevtić, B. R., (2016).Security in metro-an example for simulation of evacuation from subway, FactaUniversitatis, Working and Environmental Protection, 13(3), pp. 197-208.

19. Jevtić, B. R., (2016). Simulation of evacuation situations in order to protect human lives and material property, NBP-Journal of criminalistics and law, (2), pp. 35-49,

20. Mu, N., Song, W., Qi, X., Lu, W. and Cao, S. (2014). Simulation of Evacuation in a Twin Bore Tunnel: Analysis of Evacuation Time and Egress Selection, Procedia engineering, 71: 333-342.

21. Netcu, C., Panaitescu, V., Popa, C. and Anghel, I., (2011). 3D simulation of a subway station fire, Bucharest: Police Academy.

22. Nilsson, D., M. Johansson and H. Frantzich (2009). Evacuation experiment in a road tunnel: A study of human behavior and technical installations, Fire Safety Journal 44(4): 458-468.

23. Norén, A. and Winér, J. (2003). Modeling Crowd Evacuation from Road and Train Tunnels - Data and design for faster evacuations, Department of Fire Safety Engineering, Lund University, Sweden.

24. Persson, M., (2002). Quantitative risk analysis procedure for the fire evacuation of a road tunnel, Department of Fire Safety Engineering, Lund University, Sweden ISSN 1402-3504.

25. Ronchi, E., Colonna, P., Capote, J., Alvear, D., Berloco, N. and Cuesta, A. (2012). The evaluation of different evacuation models for assessing road tunnel safety analysis, Tunneling and Underground Space Technology 30, pp. 74-84.

26. Thunderhead, (2012). Pathfinder Example Guide, USA.

27. Valasek, L. and Glas, J., (2013). Simulation of the course of evacuation in tunnel fire conditions by FDS+Evac, Institute of 
Informatics, Slovak Academy of Sciences, Bratislava, Slovak Republic.

28. Wang, W. L. and Jacqueline, T. Y., (2014). A Simulation Study on Passenger Escape in Rail Tunnels, Procedia Engineering, 71: 552557.

29. Yang, G., Peng, L., Peng, J., Zhang, J., Zhao, M. and Yong-lin, A. (2006). Cross passage interval of super long tunnel from view of people's safe escape, Proceedings of International Symposium on Safety Science and Technology. Beijing.

30. Yang, G., Peng, L., Zhang, J. and Yong-lin, A. (2006). Simulation of people's evacuation in tunnel fire, Journal of Central South University of Technology 13, pp. 307-312.

\section{Bezbednost u tunelima-primer za simulaciju evakuacije železničkog tunela}

Apstrakt: Železnički tuneli kao specijalni objekti u smislu projektovanja $i$ realizacije predstavljaju uve kotvorenu $i$ aktuelnu temu. Posebno važan aspekt vezan za železničke tunele je evakuacija, zbog njihovih građevinskih $i$ fizičkih osobenosti $i$ nemogućnosti predviđanja potencijalnih katastrofa, kada je važno dopreti do ljudi koji mogu biti zatvoreni u tunelu i evakuisati ih zašto je moguće kraće vreme.Mogućnosti za evakuaciju u tunelima značajno opadaju u zavisnosti od uskosti tunela, mnogo bržim širenjem vatre $i$ dima nego na otvorenom prostoru, dužinom tunela i mnogim drugim razlozima. Pored mnogih teorijskih proračuna $i$ nedovršenih eksperimenata, jedan od najsigurnijih načina za predviđanje i realizaciju evakuacije je korišćenje programa za evakuaciju, kao što su Pathfinder, Evac Tunnel, Exodus i slični. Ovaj rad je napisan sa ciljem da pokaže realizovane simulacione rezultate evakuacije $u$ program Pathfinder $u$ slučaju železničkog tunela dužine 6100 metara sa evakuacionim izlazima na svakih $500 \mathrm{~m}$ i bez evakuacionih izlaza.

Ključne reči: Evakuacija, simulacija, tunel 